\title{
CHANGES IN FOLK CULTURE AND FOLKLORE ENSEMBLES
}

\section{$\underline{\text { Kristin Kuutma }}$}

The human need for the knowledge of history has increased in our contemporary world, and it is generally accompanied by the nostalgic feeling of historical continuity with past generations (Frykman-Löfgren 1987: 33-35). On the other hand, the past is usually idealized as an unsophisticated, simple "counterworld" (Bausinger 1990: 145) that is opposed to the neurotic and chaotic present day. Folklore traditions are perceived as the impersonation of that unaltered, stable and desirable "lost world" that are documented and deposited in archives in their authentic original form. The following article reflects on how this archived heritage is reanimated in the modern age and developed into a tradition in its own right. First, a few aspects elaborating the concepts of 'tradition' and 'folk song'.

The modern academic discourse on tradition argues that it is not a cultural given but a cultural construct (see Hobsbawm-Ranger 1983), invented at a certain period of time under certain circumstances. It is not relevant to judge whether a tradition phenomenon (for example, a folklore ensemble) is genuine or spurious. Tradition is neither genuine nor spurious because it is not handed down from the past as a thing or collection of things, but it is symbolically reinvented in an ongoing present (see Handler-Linnekin 1984). Tradition is not passed on from generation to generation in language, art, and music as a time-honoured body of knowledge and values, but it is rather in a constant stage of disorder and confusion, about to disintegrate under the pressure of change. And members of the society strive to restore and maintain tradition in new rituals, displays, and in diverse forms of entertainment (which are constructed, and if necessary invented), or in the revival of old ones. (Bausinger 1990: 127).

The term 'folk song' appears to convey a somewhat rigid connotation, as it embraces the idea of relating to all the people comprising a 'folk'. Folk songs have never functioned the same way for everybody in a community, they have never been current among all people, but only in particular groups of internal interactive communication, whose structure may vary considerably. In different age, people sing different songs with different companions. In its primary function, folk song is a serving object in manifestation of community life. In its secondary function folk song is experienced as a triumphant object and a spectator experience is developed (see Klusen 1986). In the contemporary society the use of the song as a tool in life-shaping experiences has been replaced in many cases by a spectator experience.

It is difficult to define the exact time when the serving object of community life of Estonian peasants developed into a triumphant object of performance culture, but surely this change is inseparably connected with the urbanisation process occurring in the industrial society. The cultivation of older forms of folk culture became an organized activity in the 1920s, its main agents being nationally-oriented museum associations, women's voluntary associations organizing handicraft courses, and youth organizations, among whom the leading position belonged to the National Estonian Youth Organization, Ülemaaline Eesti Noorsoo Ühendus or ÜENÜ (Viires 1986: 596). The Tallinn department of the latter founded a special branch for cultivating folk dance and folk rituals in 1925, and they manifested their activities as promoting "the development of omakultuur", i.e. genuine [Estonian) culture. Folk cultural festivals with grand outdoor spectacles were arranged under such national romantic titles as Voorepidu (drumlin festival), Hiiepüha (sacred grove celebration), Ilopüha (celebration of joy) (Viires 1986: 598). By 1939, ÜENÜ included 176 folk dance clubs all over Estonia with 3000 dancers (Viires 1986: 601). 
An outstanding activist in promoting folk music was August Pulst. He arranged two festivals of the Tallinn Estonian Museum as early as the beginning of the 1920s. In 1927-28 he took the troupe of the Estonian Open-Air Museum Society to five tours covering the territory of Estonia. The troupe gave all in all 244 concerts, the performers were traditional musicians (e.g. Juhan Maaker alias Torupilli (=bagpipe) Juss from Hiiumaa Island) and traditional singers (Mari Kilu from Jõelähtme parish, a Votic singer Darja Lehti), and the dancers from ÜENÜ Tallinn department. In 1932-36 the Music Museum Society continued with a similar tour, covering a more extensive area, as there were 570 performances presenting mainly ancient rituals and folk games. (Viires 1986: 599).

In the course of the past seventy years, choral singing had been developed by that time into a collective culture of Estonians, song festivals were arranged all over the country from Harjumaa county in the north to Setumaa in the south, and from the town of Narva in the east to Kuressaare in the west. The tradition to wear folk costume in a performance situation and during festivals disseminated extensively particularly through choir groups. The ideal to be achieved was to copy the costumes deposited in museums up to details, and to manifest the native region of the singer. The interchange of the inherited and the borrowed cultural elements resulted in the creation of a new version of the national culture model (Dégh 1978:43).

The cultivation of folk culture in amateur groups became popular both in urban and in rural areas, and when the cultural expression of Estonians was submitted to the guidance of Soviet cultural policy, the established system was subjected to centralized supervision. And "the cultural workers" set energetically to the development of Soviet folk culture, socialist in content and ethnic in form.

The aesthetic standard of public performance became considerably altered during the $1950 \mathrm{~s}$ in particular. Under the supervision of professional cultural workers (animators) amateur activities were shaped into a more modest form of professional art, while the latter was copied both in aesthetics and in techniques. Folk dances performed for an audience followed the standard of ballet, folk song performance departed from the classical vocal technique of chamber music, the ideal of a folk instrumentalist was expected to be music-making in a symphony orchestra. The repertoire performed was primarily humorous and gleeful, depicting the frisky and playful entertainment of the simple village folk, or the energetic workmanship achievements of the kolkhoz members.

However, parallel to the organized and institutionalized amateur activities in cultural houses, factory clubs or schools, there continued to exist the spontaneous music making, village dances and small town social dances, wedding celebrations and feasts as a constant element of communal life. The predominating repertoire, the songs and dances at these occasions did not attract the attention of cultural researchers as they remained outside the scope of ideological education, nor were they specially deposited in archives. The research objective of folklorists was targeted to a distant past, searching for "genuine" folklore heritage. Informants were not expected to perform songs and stories dominating their current repertoire, but to recall those from their childhood or early youth. For a century, the collecting of folklore in Estonia has denoted the documentation of vanavara 'the old heritage', digging up information about previous rituals and recreations from the memories of people - the more aged the better - while discarding material with a modern label as something worthless.

By the end of the 1960s the attitude towards the folk heritage paradigm changed. This phenomenon was not unique occurring in Estonia, it concurred with similar shifts of import in several European countries, e.g. in Hungary, Finland, Sweden, and Ireland. In Estonia this process was directly influenced by the massive interest in village traditions and the collective performance of unarranged folk music rising among Lithuanians, particularly among their academic youth. On the other hand, the situation in Lithuania was considerably influenced by the fact that the agrarian village 
community preserved its ancient features up to a more recent period. One significant landmark in Estonia in reintroducing the ancient musical heritage, runosongs, was the publishing of the five volumes of Eesti rahvalaule viisidega (Estonian folk songs with notations) in 1956-65. This publication of texts and melodies included a most thorough introduction in each volume, and the collection was edited by Herbert Tampere. In 1969 was published the first book of the anthology of Estonian folk songs (Eesti rahvalaulud), edited by Ülo Tedre. It is a comprehensive collection of folk song texts, and in 1974 was issued the last, eighth book of the series. In 1967 was released the first record anthology Eesti rahvalaule ja pillilugusid (Estonian folk songs and instrumental music), in 1970 followed the second LP collection. By the end of the 60s started also a radio programme introducing Estonian musical folklore, and again Herbert Tampere's name should be mentioned. And it was once more Tampere who organized a series of folk music concerts with commentaries at the Theatre and Music Museum in Tallinn (Kippar 1979).

The impact on the wider public's interest became, in turn, from the representatives of the so-called professional culture, who began manifesting respect towards the earlier layers of Estonian folklore. One should mention here the works by composer Veljo Tormis whose first folk song arrangements date from 1959, and in 1969 his choral cycle Eesti kalendrilaulud (Estonian calendar songs) was performed before an audience for the first time. An important impression made the literary works and articles by writer Jaan Kaplinski (it has been particularly stressed by those who later became active in folklore performance; see Tõnurist 1971, Smidchens 1996, Kaplinski 1969) and theatre programmes (for example, Külavahelaulud 'village songs', and dramas directed by Jaan Tooming). While discussing films, one reaches another expressive landmark (though from a more recent period) in evaluating the so-called genuine folk culture - the reinvention of the Finno-Ugric identity of Estonians: as a small nation we need a wider background in order to increase our self-esteem and find our place in global culture. Veelinnu rahvas (Waterbird people) by Lennart Meri in 1970 and especially his Linnutee tuuled (Winds of the Milky Way) in 1979 drew a clear image of our FinnoUgric identity. Also Veljo Tormis has composed several choral works based on Finno-Ugric music heritage, as has the figurative artist Kaljo Põllu in his graphical works. Starting from the end of the 70 s, the latter initiated also fieldwork trips of art students to study the material art of Finno-Ugric peoples.

The genuine traditional heritage was developed into a counterculture to ignore and oppose the officially dominating Soviet folk art. In the 1960s the first folklore ensembles were founded, though at the time they were called ethnographic ensembles or folk art ensembles. A parallel process took place in Lithuania and Latvia where, as in Estonia, the first ensembles formed were ethnographic ensembles organized by a cultural institution in a rural area. Among the first was Setu leelo choir Leiko in Värska (south-eastern Estonia), formed in 1964. On the other hand, this trend concurred with the guidelines to cultural organizers produced by a corresponding Moscow institution to be distributed all over the Soviet Union. Those guidelines provided that the genuine and living folk traditions must be introduced to the wider audience, in order to convince Soviet citizens that the Soviet cultural policy is aimed at satisfying the cultural needs of the wide masses. In 1969 was established the ensemble Leigarid, in 1971 Leegajus, 1972 Hellero, 1973 Sõsarõ, 1975 Lahemaa rahvamuusikud 'folk musicians from Lahemaa'. The official impulse for founding Leigarid was the intention to demonstrate the songs and dances of ancient Estonians to foreign tourists visiting the Open-Air Museum in Tallinn, as the number of foreign guests visiting the capital was growing remarkably. But the significant change in mentality was actually reflected by the urge of the leader of the ensemble, Kristjan Torop, to educate himself and the dancers in traditional dance, which resulted in ignoring the current established performance canon for "folk dance", and that in turn caused disparagement among the merited dance activists. Leegajus (leader Igor Tõnurist) and Hellero (lead by brothers Sarv, Paul Hagu and Viktor Danilov) represented the vogue among the 
urbanized youth to admire and idealize the peasant culture. The performance style of Leegajus was closer to a theatrical presentation, more so directed to an audience; Hellero functioned actually like a club for a circle of friends. The members of these urban ensembles regarded runosong to be "the most natural song" (Sarv 1982), though the general repertoire of Estonians had changed quite radically starting from the beginning of the present century. That was the case also in Kihnu Island and in Setumaa, which were officially regarded as the last resorts for the masters of the ancient singing style, but where even the direct tradition bearers gathered as a registered ensemble at the village cultural house in order to perform the runosong heritage. The local youth already entertained themselves generally with a different kind of song repertoire.

The establishing of such recontextualized folklore ensembles, however, did not become a massive movement in Estonia until the second half of the 1980s. One major factor in this respect was the opposition between the so-called official culture and the folklore movement. It should be mentioned, that academic folklorists did not particularly appreciate the activities of folklore ensembles either, the only stage performances recognized were those by Kihnu or Setu folk tradition ensembles. The youth of urban descent were regarded simply as copycats of a fine art, excluding completely the possibility to see them as tradition bearers. To the cultural administrators, the evolved alteration in the aesthetic paradigm was largely incomprehensible and unacceptable. They perceived the ignoring of the established concert performance canon above all as a technical inaptitude and a lack of the obligatory stage training. Thus the official cultural policy did not support such folklore activities. But those folklore ensembles presented to the audience a new semantic system in interpreting traditional culture, and gradually a resonance was created. Organized and collective recreational events, and the growing popularity of celebrating folk calendar festivals together with one's colleagues in a factory, kolkhoz or office created a demand for competent performers in the entertainment programme. And therefore folklore ensembles offering a stage programme of the ancient peasant traditions were popular entertainers both in cities and in villages.

In the 80 s a change of attitude becomes gradually apparent. The runosong heritage reached the widest cultural masses in the choral compositions by Veljo Tormis, the popularity of which grew rapidly. Since the late 70 s folk music days were arranged in different parts of Estonia, which included also a competition for musicians that assisted in bringing forth again the village instrumentalists. In 1976 was started a regular series of international folk music conferences, the programme of which included concerts presenting various folklore ensembles of different FinnoUgric peoples.

In the middle of the $80 \mathrm{~s}$ there occurred also a major shift in the principles of the cultural administrators, though it did not happen completely overnight. The Moscow officials picked Estonia as the most suitable place for arranging the 1985 general assembly of the world organization of folklore festivals (CIOFF, Conseil International des Organisations de Festivals de Folklore et d'Arts Traditionelles). This event testified to the development of new trends in Soviet cultural policy, primarily the aspiration to demonstrate themselves as appreciating and promoting the genuine traditional culture. In 1986 in Estonia was arranged the first event under the title "folklore festival", Viru säru in Palmse (northern Estonia). The next year took place the first international folklore festival Baltica in Lithuania, the next year that touring festival was arranged in Latvia, and in 1989 it was Estonia's turn. The emergence of such an arena brought about an expansion of the folklore movement, and the integration of manifested folklore programmes in the repertoire of a large number of dance and music collectives that previously had presented only arrangements or authorized repertoire. 
In 1990 in Viljandi Cultural College was established a department of folk music, which can be regarded as the outset of new trends and a new quality in Estonian folk music activities. Today the number of folklore ensembles, their place in the cultural landscape and their membership has undergone several changes.

\section{References}

Bausinger, H. 1990. Folk Culture in a World of Technology. Translated by Elke Dettmer. Bloomington, Indiana.

Dégh, L. 1978. The Study of Ethnicity in Modern European Ethnology. Folklore, Nationalism and Politics. Ed. by Felix Oinas. Columbus, Ohio.

Frykman, J., Löfgren, O. 1987. Culture Builders: A Historical Anthropology of Middle-Class Life. Translated by Alan Crozier. New Brunswick.

Handler, R., Linnekin, J. 1984. Tradition, Genuine or Spurious. Journal of American Folklore no. 97, 273-290.

Hobsbawm, E., Ranger, T. (eds.) 1983. The Invention of Tradition. Cambridge.

Kaplinski, J. 1969. Pärandus ja pärijad. Sirp ja Vasar 1969, 9 (28 February).

Kippar, P. 1979. Osalemisrõõmust. Sirp ja Vasar 1979, 7 (28 September).

Klusen, E. 1986. The Group Song as Object. German Volkskunde. Bloomington, Ind.

Smidchens, G. 1996. A Baltic Music: The Folklore Movement in Lithuania, Latvia, and Estonia, 1968-1991. UMI Dissertation Services. Ann Arbor, Michigan.

Sarv, T. 1982. Hellero. Sirp ja Vasar 1982, 12 (4 June).

Tõnurist, I. 1971. Laaliku minu isädä... Sirp ja Vasar 1971, 6 (13 August).

Viires, A. 1986. Folklorismi sünd Eestis. Keel ja Kirjandus 1986/10: 595-602. 